\title{
Bladder Cancer pT3a TNM Finding v6 and
} v7

National Cancer Institute

\section{Source}

National Cancer Institute. Bladder Cancer pT3a TNM Finding v6 and v7. NCI Thesaurus. Code C61214.

Bladder cancer with microscopic invasion into the perivesical tissue. (from AJCC 6th and 7th Eds.) 